Al-Huquq: Journal of Indonesian Islamic Economic Law, 3 (1), 2021: 81-95

ISSN: 2715-0003; E-ISSN 2714-5514

DOI: http://doi.org/10.19105/alhuquq.v3i1.3106

\title{
Penerapan Akad Jual Beli di Toko Modern dalam Pandangan Hukum Ekonomi Syariah (Studi Kasus di Toko Basmalah Pulau Mandangin Kabupaten Sampang)
}

\author{
Wasilatur Rohmaniyah, Anas \\ (Fakultas Syariah IAIN Madura Jl. Raya Panglegur Km. 4 Pamekasan 69371)
}

\begin{abstract}
Abstrak:
Penelitian ini membahas tentang perkembangan praktik jual beli di era modern, di mana ketiadaan ijab dan qabul secara ekplisit menjadi suatu hal yang lumrah. Berdasarkan hal tersebut, ada dua permasalahan yang menjadi kajian pokok dalam penelitian ini, pertama, bagaimana penerapan akad jual beli di toko Basmalah Pulau Mandangin; kedua, bagaimana penerapan akad jual beli di toko modern dalam pandangan hukum ekonomi syariah. Penelitian ini merupakan penelitian deskriptif dengan menggunakan pendekatan kualitatif. Sumber data diperoleh melalui wawancara, observasi dan dokumentasi. Informannya adalah jajaran staff toko Basmalah cabang Pulau Mandangin, pelanggan dan tokoh masyarakat. Sedangkan pengecekan keabsahan data dilakukan melalui perpanjangan keikutsertaan, ketekunan pengamatan, triangulasi, analisis kasus negatif dan uraian rinci. Hasil penelitian menunjukkan bahwa: pertama, pelaksanaan akad jual beli di toko modern di Pulau Mandangin ini menggunakan barcode dan pelanggan diperbolehkan mengambil produk/barang yang inginkan; kedua, mengenai transaksi jual beli di toko modern, ulama berbeda pendapat sebagian ulama tidak membolehkan karena akad itu harus jelas dan sebagian ulama lainnya membolehkan, seperti Ibnu Syuraih berpendapat sebagaimana firman Allah telah menghalalkan jual beli dan tidak ada lafal khusus untuk hal tersebut sehingga diperbolehkan memakai adat kebiasaan yang berlaku. (This study discusses the development of buying and selling practices in the modern era, where the absence of consent and qabul is explicitly becoming a common thing. So, there are two problems which is the main idea in this case; first, how the implementation of the sale and purchase agreement at the Basmalah store of Mandangin Island; second, how is the application of the sale and purchase agreement in a modern store in the view of Islamic
\end{abstract}

email koresproden: wasilatur@iainmadura.ac.id

https://creativecommons.org/licenses/by-nc/4.0/

Copyright (c) 2019 by al-huquq. All Right Reserved 
economic law. This research is a descriptive study by using a qualitative approach. Sources of data obtained through interviews, observation and documentation. The informants were the staff of the Basmalah store branch of Mandangin Island, customers and community leaders. While checking the validity of the data is done through extended participation, perseverance of observation, triangulation, negative case analysis and detailed description. The results showed that: first, the implementation of the sale and purchase agreement at this modern shop on Mandangin Island used barcodes and customers were allowed to take the products / items they wanted comfortably; secondly, regarding buying and selling transactions in modern stores, some scholars disagree, it do not allow because the contract must be pronounced clearly, while some others allowed, as Ibn Syuraih which is though that God has justified the sale and purchase and there is no specific pronunciation for that matter so it is permissible to use prevailing customs).

Kata Kunci:

Jual beli, toko modern, ijab qabul, pulau Mandangin

\section{Pendahuluan}

Perdagangan atau transaksi jual beli merupakan praktik yang sudah lama berkembang seiring dengan kehidupan manusia beserta dinamikanya. Transaksi terjadi seiring dengan kebutuhan manusia terhadap harta untuk memenuhi hajat hidup mereka. Di Pulau Mandangin, Kabupaten sampang untuk memenuhi kebutuhannya masyarakat melakukan kegiatan transaksi atau jual beli. Tentunya akan berbeda antara transaksi toko-toko biasa dan pasar-pasar dengan toko modern (Indomart, Alfamart, Basmalah, Mini Market) di toko tersebut jika melakukan kegiatan transaksi antara kasir dan pelanggan tidak jelas ijab dan qabulnya atau akadnya, lain halnya dengan di toko biasa, ijab serta qabulnya jelas sehingga penjual dengan pelanggan dapat memahaminya. Ahmad Ainul Yakin (23 Tahun), salah satu pelanggan toko Basmalah di Pulau Mandangin, mengatakan:

"Transaksi antara rumah toko (ruko) dengan toko modern berbeda, jika rumah toko akad serta ijab dan qabulnya jelas, (saya 
Penerapan Akad Jual Beli di Toko Modern dalam Pandangan Hukum Ekonomi Syariah (Studi Kasus di Toko Basmalah Pulau Mandangin Kabupaten Sampang)

beli, dengan harga tersebut, saya terima) lain dengan toko modern yang kurang begitu jelas ijab dan qabulnya."1

Dalam rangka pemenuhan kebutuhan hidup, maka digariskan norma dan aturan agar tercipta sebuah transaksi yang harmonis. Norma atau aturan tersebut bisa saja digariskan oleh pemerintah dalam sebuah aturan hukum, dan juga bisa saja digariskan oleh agama yang diyakini oleh pemeluknya. Dalam konteks ini, aturan agama tersebut tidak hanya menjadi rambu dalam transaksi, namun sudah menjadi sebuah keyakinan yang dipercaya berdampak terhadap tidak sahnya sebuah transaksi dan berdosa bagi pelanggarnya dan juga sah serta berpahala bagi yang melaksanakan sesuai dengan agama tersebut.

Islam dalam hal ini bukan hanya sebuah keyakinan saja, namun Islam diyakini oleh para pemeluknya sebagai sebuah agama yang mengajarkan jalan hidup (way of life), baik jalan hidup yang berdimensi duniawi juga ukhrawi. Dalam hal kehidupan duniawi, khususnya bermuamalat, Islam menggariskan norma yang jelas dengan memberikan aturan yang umum seiring dengan dinamika masyarakatnya. ${ }^{2}$

Menurut Sakinah, Akad ialah suatu perikatan yang dilakukan oleh dua orang atau lebih berdasarkan ijab dan qobul dengan adanya ketentuan syar'i. sedangkan ijab merupakan pernyataan yang keluar dari orang yang menyerahkan barang, dan qobul adalah ucapan yang dilakukan oleh pembeli dengan ucapan menerima atas ijab yang dilakukan oleh penjual. ${ }^{3}$

Menurut Abdul Aziz Muhammad Azzam, Al-Mut'ah dan AlMunawalah berasal dari kata 'atha-yu'ti, jika dia saling memberi bentuk mufa'alah (saling bekerja) dari kata 'atha' saling menyerahkan tanpa ada akad. Jual beli mu'athah adalah jual beli yang hanya dengan penyerahan dan penerimaan tanpa adanya ucapan atau ada ucapan tetapi dari satu pihak saja namun kemundian ahli fiqih memakainya

1 Ahmad Ainul Yakin, "Pelanggan Toko Basmalah, Wawancara Langsung, (27 Oktober 2017)."

2 Rusdiyah, "Shigat Ijab Kabul Transaksi Jual Beli: Perspektif Ulama Kalimantan Selatan," Al-Banjari 14, no. 2 (2015): 109.

3 Sakinah, Fiqih Mu'amalah (Pamekasan: STAIN Pamekasan Press, 2006), 21-22. 
untuk jual beli yang bersifat saling memberi secara khusus. Abdul Aziz Muhammad Azzam dalam literaturnya juga mengutip dari ulama yang masyhur menyebutkan bahwa:

"Pendapat yang masyhur dari mazhab kami bahwa tidak sah jual beli dengan $m u^{\prime}$ athah baik dalam jual beli yang sedikit atau banyak, dan pendapat inilah yang dipegang kuat oleh penulis dan jumhur ulama. Sudah menjadi kebiasaan orang bahwa menganggap sah membeli barang-barang kecil (tidak begitu berharga) tanpa ucapan ijab dan qabul, sedangkan jika yang dijual barang berharga, maka tidak sah kecuali dengan ijab dan qabul, dan menilai satu barang apakah berharga atau tidak dikembalikan kepada adat kebiasaan setempat. Jika ia dianggap barang tidak berharga, maka sah jual beli tanpa ucapan ijab dan qobul dan jika barang berharga, maka harus ada ijab dan qobul. Ini adalah pendapat yang terkenal dalam pembahasan sahnya jual beli dengan $m u^{\prime}$ athah". ${ }^{4}$

Shigat akad berupa perbuatan dalam literatur fiqih dikenal dengan konsep ta'athi atau mua'atah, yang dimaksud dengan konsep ini adalah bahwa para pihak yang bertransaksi tidak menggunakan kata, isyarat ataupun tulisan dalam menyatakan persetujuannya terhadap transaksi yang mereka lakukan, namun dengan cara perbuatan langsung untuk menutup transaksi yang merekalakukan. ${ }^{5}$

Syaikh Sulaiman Ahmad Yahya Al-Fifi mengklasifikasikan syarat-syarat sighat (ijab dan qabul) menjadi dua macam yakni; pertama, kedua belah pihak harus saling bertemu di satu tempat; kedua, adanya kesesuaian antara ijab dan qabul dalam kaitannya dengan harga dan barang. Seandainya si penjual berkata, aku menjual baju ini kepadamu dengan harga lima dirham," lalu si pembeli menimpali, "aku menerimanya dengan harga empat dirham," maka jual beli di antara keduanya tidak sah karena terdapat perbedaan antara ijab dan qobul. Ketiga, lafazh ijab dan qobul harus menggunakan kata kerja lampau (madhi), seperti perkataan bi'tu (aku telah menjual) dan qabiltu (aku telah menerimanya), atau kata kerja

4 Abdul Aziz Muhammad Azzam, Fiqih Muamalat Sistem Transaksi dalam Fiqih Islam (Jakarta: Amzah, 2010), 34-35.

${ }^{5}$ Rusdiyah, "Shigat Ijab Kabul Transaksi Jual Beli: Perspektif Ulama Kalimantan Selatan," 201. 
Penerapan Akad Jual Beli di Toko Modern dalam Pandangan Hukum Ekonomi Syariah (Studi Kasus di Toko Basmalah Pulau Mandangin Kabupaten Sampang)

sekarang (mudhari'), seperti abi'u (aku akan menjual) dan asytari (aku akan membeli). ${ }^{6}$

Di Pulau Mandangin misalnya yang masih layak dikatakan awam meskipun sudah banyak pelajar, dan banyak di daerah-daerah lainnya khusunya perkotaan di toko-toko modern (Indomart, Alfamart, Basmalah, Mini Market, dan lain-lain), di sana ketika melakukan kegiatan transaksi jual beli antara pembeli dan penjual tidak menerapkan ijab dan qabulnya, hanya saja menerapkan mesin yang tersedia di toko tersebut, berbeda dengan jaman dulu sebelum adanya toko modern atau di pasar-pasar dan di toko kecil, disana lebih jelas ijab dan qabulnya.

Selain itu, berdasarkan pengalaman peneliti, ketika peneliti membeli suatu barang di salah satu toko modern seperti toko basmalah selaku objek dari penelitian ini, di sana (toko modern) jika melakukan transaksi jual beli akad dan ijab kabulnya tidak begitu jelas diterapkan, lain dengan toko tradisional yang begitu tampak jelas diterapkan.

Dari permasalahan di atas maka peneliti berkeinginan untuk mebahas bagaimana Penerapan Akad Jual Beli di Toko Modern Dalam Pandangan Hukum Ekonomi Islam (Studi Kasus di Pulau Mandangin, Kabupaten Sampang). Melalui penelitian ini penulis berharap agar para pembeli (pelanggan) masyarakat Pulau Mandangin merasa puas dan tidak merasa dirugikan, di mana mayoritas masyarakatnya dapat dikategorikan masih awam. Berdasarkan konteks penelitian tersebut, maka fokus kajian dalam penelitian ini adalah seputar bagaimana penerapan akad jual beli di toko Basmalah pulau Mandangin, Kabupaten Sampang dan bagaimana penerapan akad jual beli di toko modern dalam pandangan hukum ekonomi Syariah.

\section{Metode Penelitian}

Jenis penelitian ini menggunakan jenis penelitian empirisdeskriptif yaitu "data yang dikumpulkan adalah berupa kata-kata, gambar, dan bukan angka-angka. Hal ini disebabkan oleh adanya penerapan metode kualitatif. Selain itu semua yang dikumpulkan

6 Syaikh Sulaiman Ahmad Yahya Al-Fifi, Ringkasan Fiqih Sunnah Sayyid Sabiq (Jakarta: Pustaka Al-Kautsar, 2009), 751. 
berkemungkinan menjadi kunci terhadap apa yang sudah diteliti" ${ }^{7}$ Penelitian ini menggunakan pendekatan kualitatif untuk menggambarkan secara menyeluruh tentang Penerapan Akad Jual Beli di Toko Modern Dalam Pandangan Hukum Ekonomi Syariah, di mana peneliti hanya terfokus pada bagaimana akad jual beli di toko modern Basmalah, Pulau Mandangain, Kabupaten Sampang.

\section{Pengertian Akad}

Menurut Hisyam Ifham Sholihin definisi akad secara bahasa berarti ikatan (Al-ribthu), perikatan, perjanjian, dan pemufakatan (alIttifaq). Dalam Fiqih didefinisikan dengan irtibathu, ijabin biqobulin 'ala wajhin masyru'in yasbutu atsaruhu fi mahalihi, yakni pertalian ijab (pernyataan melakukan ikatan) atau qabul (peryataan penerimaan ikatan) sesuai dengan kehendak syariat yang berpengaruh pada objek perikatan. Akad juga didefinisikan dengan kontrak atau kedua belah pihak serta kesepakatan tertulis antara bank syariah dan pihak lain yang memuat ijab (penawaran) dan qabul (penerimaan) antara bank dan pihak lain yang berisi hak dan kewajiban masing-masing pihak sesuai dengan prinsip syari'ah. ${ }^{8}$

\section{Rukun dan Syarat-Syarat Akad}

Ika Yunia Fauzia dan Abdul Kadir Riyadi dalam bukunya Prinsip Dasar Ekonomi Islam Perspektif Maqasid al-Syari'ah, mengemukakan beberapa rukun akad dalam Islam sangat bertujuan untuk menjaga kemaslahatan di antara manusia. ${ }^{9}$ Perpindahan kepemilikan diharuskan melalui jalur empat rukun dengan alasan untuk menjaga hak manusia dari penipuan, kecurangan dan ketidakadilan, yaitu:

1. Subyek perikatan (al-aqidayn)

2. Obyek perikatan (mahallul aqd)

${ }^{7}$ Lexy J. Moleong, Metodologi Penelitian Kulitatif, (Bandung: Remaja Rosda Karya, 2005), hlm, 4

${ }^{8}$ Ahmad Ifham Sholihin, Buku PintarEkonomi Syaria (Jakarta: Gramedia Pustaka Utama, 2010), 18-19.

9 Ika Yunia Fauzia dan Abdul Kadir Riyadi, Prinsip Dasar Ekonomi Islam Perspektif Maqasid Al-Syari'ah (Jakarta: Prenadamedia Goup, 2014), 23738. 
Penerapan Akad Jual Beli di Toko Modern dalam Pandangan Hukum Ekonomi Syariah (Studi Kasus di Toko Basmalah Pulau Mandangin Kabupaten Sampang)

3. Bentuk kesepakatan perikatan ijab dan qabul (shighah alaqd), dan

4. Tujuan perikatan (mawdhu'ul aqd).

\section{Akibat Hukum dan Berakhirnya Akad}

Berakhirnya atau batalnya akad adalah akad yang kurang rukun dan atau syarat-syaratnya. ${ }^{10}$ Dalam sumber lain menyebutkan akad berakhir dengan penuh pembatalan, meninggal dunia, atau tanpa adanya izin dalam akad mauqud (ditangguhkan). ${ }^{11}$ Akad habis dengan pembatalan contohnya seperti akad Ghair Lazim, yang kedua pihak dapat membatalkan akad, pembatalan ini sangat jelas, seperti pada penitipan barang perwakilan, dan lain-lain, atau yang Ghair Lazim pada suatu pihak dan lazim pada pihak lainnya. Seperti gadai, orang yang menerima gadai dibolehkan membatalkan akad walaupun tanpa sepengetahuan orang yang mengadaikan barang. Adapun pembatalan pada akad lazim, terdapat dalam beberapa hal:

1. Ketika akad rusak

2. Adanya khiyar

3. Pembatalan akad

4. Tidak mungkin melaksanakan.

\section{Pengertian, Macam dan Bentuk, Serta Rukun dan Syarat Jual Beli}

Jual beli adalah menukar barang dengan barang yang lain atau menukar harta dengan harta melalui cara tertentu dan saling suka sama suka, serta terhindar dari riba.

Macam atau jenis jual beli disini dilihat dari bentuk pembayaran dan waktu penyerahan barang, Lukman Hakim dalam bukunya dibagi menjadi 3 (tiga) macam, yaitu:

1. Ba'i al-Murabahah. ${ }^{12}$

2. Ba'i as-Salam. ${ }^{13}$

3. Ba'i al-Istishna. ${ }^{14}$

\footnotetext{
${ }^{10}$ Ika Yunia Fauzia dan Abdul Kadir Riyadi, 19.

11Sakinah, Fiqih Mu'amalah, hlm., 28.

${ }^{12}$ Lukman Hakim, Prinsip-prinsip Ekonomi Islam, hlm., 116-117.

${ }^{13} \mathrm{Ibid}, \mathrm{hlm} ., 118$.

${ }^{14}$ Ibid, hlm., 119.
} 
Adapun syarat-syarat jual beli sesuai dengan rukun jual beli yang dikemukakan oleh jumhur ulama ada sebagai beikut:

1. Syarat-syarat orang yang berakat.

2. Syarat-syarat yang terkaid dengan ijan qabul. ${ }^{15}$

3. Syarat-syrat yang dijual-belikan.

\section{Tinjauan Tentang Jual Beli Dengan Sistem $A l-M u^{\prime} a t h a h$}

Abdul Aziz Muhammad Azzam mendefinisikan al-mu'athah dan al-munawalah berasal dari kata 'atha yu'thi jika dia saling memberi bentuk mufa'alah (saling bekerja) dari kata 'atha' yaitu saling menyerahkan tanpa ada akad. Jual beli dengan sistem mu'athah adalah jual beli yang hanya dengan penyerahan dan penerimaan tanpa ada ucapan atau ada ucapan tetapi dari satu pihak saja namun kemudian kalangan ulama ahli fiqih memakainya untuk jual beli yang bersifat saling memberi secara khusus. ${ }^{16}$ Dan Ahmad Ifhan Sholihin menyatakan bahwa bai' muathah adalah salah satu bentuk akad jual beli yang berlangsung tanpa ada ucapan ijab qabul dari pihak pembeli atau penjual. Bai' muathah ini banyak dipraktikkan dalam sistem perdagangan konvensional, seperti jual beli yang berlangsung di supermarket atau mal. ${ }^{17}$

\section{Profil Toko Basmalah}

Pada bagian ini akan dipaparkan tentang hal-hal yang berkaitan dengan temuan-temuan penellitian yang telah dilakukan peneliti melalui wawancara, observasi dan dokumentasi. Tetapi sebelum data yang berkenaan dengan fokus masalah dipaparkan maka terlebih dahulu perlu kita ketahui tentang profil satu-satunya toko modern yang ada di Pulau Mandangin Kabupaten Sampang yakni toko Basmalah yang meliputi struktur, tugas dan tanggung jawab karyawan, serta produk asli toko basmalah.

Toko pusat basmalah terletak di Jl. Raya Sidogiri-Warungdowo No. 18, Sidogiri, Kraton, Pasuruan, Jawa Timur 67151. Toko basmalah Pulau Mandangin yang merupakan cabang termasuk dalam wilayah

${ }^{15} \mathrm{Abd}$. Hadi, Dasar-dasar Hukum Ekonomi Islam,hlm., 53-54.

${ }^{16}$ Abdul Aziz Muhammad Azam, Fiqih Muamalat Sistem Transaksi Dalam Islam, hlm., 35.

${ }^{17}$ Ahmad Ifham Sholihin, Buku Pintar Ekonomi Syariah, hlm., 142. 
Penerapan Akad Jual Beli di Toko Modern dalam Pandangan Hukum Ekonomi Syariah (Studi Kasus di Toko Basmalah Pulau Mandangin Kabupaten Sampang)

kecamatan Sampang kabupaten Sampang, terletak di dusun tengah/dusun Keramat RT: 002 / RW: 003. Toko Basmalah yang merupakan milik Koperasi Pondok Pesantren (Kopontren) Sidogiri, Pasuruan, Jawa Timur, yang sudah beroperasi di berbagai Kabupaten di Pulau Jawa dan Kalimantan dan selama ini sudah sesuai.

Secara prinsipil Toko Basmalah memang tidak sama dengan Indomaret dan Alfamart. Setidaknya empat poin yang membedakan Toko Basmalah milik Pondok Pesantren Sidogiri dengan toko modern yang lain, yaitu; Pertama, Bahwa sebagian modal Toko Basmalah bersumber dari iuran masyarakat sekitar, dan anggota masyarakat sekitar dapat bergabung serta menjadi anggota Toko Basmalah dengan iuran keanggotaan yang sangat terjangkau sehingga Toko Basmalah dapat dimiliki banyak orang dengan sistem kerjasama.

Kedua, toko Basmalah menerima komoditi dagangan dari masyarakat atau UKM sekitar dengan prosedur yang mudah dan biaya registrasi yang murah. Ketiga, toko Basmalah menerapkan starategi harga yang berbeda untuk konsumen dari masyarakat yang ingin kulakan, dan dijual kembali sesuai dengan harga eceran yang berlaku di Toko Basmalah dan pasar setempat. Keempat, komoditi barang jualan halal dan baik. Inilah poin-poin yang membedakan antara Toko Basmalah dengan toko-toko modern.

Berdasarkan pengalaman pelanggan toko Basmalah "semalam saya menemukan pengalaman yang berbeda. Saya memang sudah terbiasa belanja di toko Basmalah, tapi luar biasanya adalah waktu saya masuk, Salam dari pelayan basmalah adalah kalimat pertama untuk menyambut customer, bukan lagi lagu band, apalagi dangdut koplo yang mengalun, melainkan lantunan ayat-ayat suci yang menyentuh hati. Ketika saya sedang mencari barang untuk dibeli, pelayan Basmalah lewat di samping saya dengan mengucapkan permisi, bertingkah laku sopan layaknya seorang santri.

Kemudian yang terakhir adalah waktu saya melakukan pembayaran di kasir, yang melayani di kasir melakukan mu'amalah yang sesuai dengan tuntunan madzhab Syafi'i. Dia bilang: "saya jual". Saya tidak segera menjawabnya karena tertegun sebab sudah lama tidak mendengar shighat akad ketika jual beli, apalagi di toko ritel modern. Biasanya paling adanya di toko kitab. Seharusnya, memang tiap transaksi yang melibatkan uang yang tidak sedikit seharusnya dibarengi dengan akad serah terima. Penjualnya mengatakan "saya 
jual", sedang pembelinya mengatakan "saya beli". Dengan ini maka transaksi dianggap nufudh (terlaksana). Tetapi jarang sekali orang zaman sekarang yang mempraktekkan ini, bahkan yang banyak terjadi adalah transaksi dengan sistem mu'athoh (transaksi tanpa ucapan serah terima), meskipun sebenarnya secara fiqih jual beli mu'athoh hanya dibenarkan ketika barangnya sepele. Senang sekali berbelanja di toko yang mendapat pelayanan setulus hati dan sesuai aturan syar'i. Ini pengalaman yang membuat saya merasakan sensasi yang berbeda" ${ }^{18}$

Saat ini Kopontren Sidogiri telah memiliki 72 cabang di beberapa beberapa kabupaten dan kota di Provinsi Jawa Timur seperti Pasuruan, Probolinggo, Bondowoso, Situbondo, Banyuwangi, Jember, Malang, Lamongan, Bangkalan, Pamekasan, Sampang dan Sumenep. Kedepan Kopontren Sidogiri akan terus berupaya untuk terus melakukan inovasi dan menjadi yang terdepan dalam bisnis ritel. Sejak 2013 Kopontren Sidogiri membentuk infrastruktur brand "BASMALAH" dengan nama "TOKO BASMALAH" dengan motto "Tempat Belanja yang Baik". 19

Muhlisol atau yang sering dipanggil dengan panggilan abah Muhlisol, merupakan salah satu tokoh mayarakat Pulau Mandangin, tidak hanya itu beliau adalah alumni santri sidogiri dan juga sebagai pengawas toko Basmalah yang ada di Pulau Mandagin. Muhlisol menambahkan sejak tahun kurang lebih 80-an bisnis pondok pesantren Sidogiri berkembang di bidang kopontren (koperasi pondok pesantren) yang dimulai dari usaha kecil-kecilan.

Salah satu penggagas di Madura ialah kiyai Mudazir, beliau merupakan pengasuh pondok pesantren Palengaan Pamekasan. Dari tahun-ke tahun mulai berkembang pesat sehingga mempunya tiga unit yang setiap tahunnya pendapatannya kurang lebih 187 juta pada tahun 1982-1983. Tiga unit tersebut ialah; pertama, bergerak dibidang kebutuhan para santri dan masyarakat yakni pakain, kitab-kitab. Dan unit kedua adalah sejenis warung yang bertujuan melayani para

${ }^{18}$ http:// www.maqonsae.com/2017/12/pengalaman-belanja-di-tokobasmalah.html?m=1.DiaksesTanggal 12 Maret 2018.

${ }^{19} \mathrm{http}: / /$ bmtugtsidogiri.co.id/berita-220.html. diakses tanggal 12 Maret 2018. 


\section{Penerapan Akad Jual Beli di Toko Modern dalam Pandangan Hukum Ekonomi Syariah (Studi Kasus di Toko Basmalah Pulau Mandangin Kabupaten Sampang)}

santri yang indikos, edangkan unit ke tiga merupakan peracangan yang semua kebutuan pada waktu itu isyaallah ada.

Seiring berjalannya waktu dan perkembangan zaman maka berkembanglah usaha tersebut hingga mempunyai gagasan untuk membuka cabang di luar pondok peantren yang berkonsep toko modern dan dinamakan toko "BASMALAH". Kurang lebih 200 cabang yang berada hampir di setiap kecamatan dan kabupaten sampai ke plosok desa pun ada, sehingga sampai di pulau Mandangin, yang sasarannya juga untuk mengimbagi usaha perekonomian penduduk yang bukan pribumi.

Keberadaan toko Basmalah di Pulau Mandangin disambut positif oleh para alumni dan masyarakat setempat, terbukti pada saat pertama kali buka (launcing) toko basmalah langsung beromset kurang lebih 40 juta. Hingga saat ini pedapatan toko basmalah mencapai kurang lebih 15 juta perhari.

Dalam membangun ekonomi syariah pihak pondok pesantren tidak meminta bantuan dana dari pemerintah melainkan mengandalkan aset milik pondok pesanten. Oleh karena itu, pengelolaan atau managemen toko basmalah sangat idependen, tidak dipengaruhi oleh pihak luar, sehingga penerapan aspek muamalah menjadi mudah dan menyeluruh. ${ }^{20}$

\section{Penerapan Akad Jual Beli di Toko Modern Basmalah Pulau Mandangin, Kabupaten Sampang}

Berdasarkan paparan data yang telah diuraikan di atas dapat dirumuskan beberapa hasil penelitian sebagai berikut: Jual beli di Toko Basmalah Pulau mandangin nenggunakan media elektronik yang dinamakan "barcode". Barcode merupakan kode batang berbentuk garis atau bar yang hanya dapat dibaca oleh mesin. Pada toko atau pusat perbelanjaan barcode menyimpan seluruh informasi tentang produk seperti tanggal produksi dan kadaluarsa produk, nomor identitas produk, termasuk juga harganya. Dengan adanya teknologi ini, jual beli tidak lagi perlu menggunakan ucapan ijab dan qabul, karena pembeli cukup dengan memilih produk yang ingin

${ }^{20}$ Muhlisol, Pengawas Manajemen Toko Basmalah Cabang Pulau Mandangin. Wawancara Langsung, (02 Maret 2018). 
dibeli dan menyerahkannya ke kasir sebagai bentuk persetujuan membeli.

Dengan adanya barcode ini, maka pembeli dianggap sudah paham dengan beberapa ketentuan sebagai konsekwensinya, antara lain: pembeli diberikan hak seluas-luasnya untuk memilih barang yang akan dibelinya; dengan menyerahkan barang ke kasir, artinya dia telah setuju untuk membeli barang tersebut; dan barang yang sudah dibeli tidak bisa dikembalikan kembali. Jual beli ini tentu memudahkan bagi pembeli, karena proses khiyar dapat terakomodasi dan pembeli merasa nyaman. ${ }^{21}$

Jual beli ini telah menjadi kebiasaan masyarakat, sehingga sebagaimana pendapat para ulama dari kalangan Malikiyyah dan Hanabilah menyebutkan tentang sahnya jual beli mu'athah ini, selama hal itu menjadi kebiasaan masyarakat setempat, sehingga menunjukkan adanya keridhaan dari kedua belah pihak (penjual dan pembeli).

\section{Penerapan Akad Jual Beli di Toko Modern Basmalah Pulau Mandangin Kabupaten Sampang dalam Pandangan Hukum Ekonomi Syariah.}

Dari hasil observasi dan wawancara peneliti menemukan bahwa akad jual beli di toko modern dalam pandangan hukum ekonomi syariah adalah bentuk jual beli al-Mu'athah, di mana almu'athah adalah jual beli yang dilakukan hanya dengan penyerahan dan penerimaan tanpa ada ucapan dari kedua belah pihak atau kalaupun ada ucapan tetapi dari salah satu pihak saja.

Para ulama berbeda pandangan megenai al-mu'athah ini, ada ulama yang membolehkan dan ada pula ulama yang melarangnya. Ulama syafi'iyah tidak membolehkan dengan alasan bahwa unsur kerelaan perlu diungkapkan melalui kata-kata secara jelas. Sedangkan pendapat yang masyhur dari Ibnu Syuraih bahwa akad jual beli sah dengan mu'athah karena Allah menghalalkan jual beli dan dalam syara' tidak ada lafal khusus mengenai hal ini sehingga boleh disesuaikan dengan adat atau kebiasaan penduduk yang sudah mejadi kesepakatan bersama.

${ }^{21}$ Ainur Rosi, salah satu karyawan Toko Basmalah Cabang Pulau Mandangin, Wawancara Langsung (02 Maret 2018) 


\section{Penerapan Akad Jual Beli di Toko Modern dalam Pandangan Hukum Ekonomi Syariah (Studi Kasus di Toko Basmalah Pulau Mandangin Kabupaten Sampang)}

Bertransaksi seperti jual beli boleh dilaksanakan dimanapun asalkan barang yang dibeli tidak mengandung unsur riba, dan kedua belah pihak tidak ada yang merasa dirugikan sehingga timbul saling ridha (an taradiin). Berkenaan dengan ijab dan qabul, bahwa ijab dan qabul tidak harus diucapkan secara eksplisit, karena dengan penyerahan barang dan uang mengandung makna terjadinya ijab dan qabul.

Jual beli al-mu'athah di mana para pihak yang bertransaksi tidak menggunakan kata, isyarat ataupun tulisan dalam menyatakan persetujuannya terhadap transaksi yang mereka lakukan, melainkan dengan cara perbuatan langsung, sudah menjadi kebiasaan masyarakat umumnya di toko-toko besar. Di zaman modern seperti saat ini penggunaan teknologi seperti barcode sudah menjelaskan harga suatu barang, dan pembayaran sesuai dengan harga yang tertera pada barcode tersebut merupakan bentuk persetujuan pembelian. Jika konsumen setuju terhadap harga barang yang dipilih, maka konsumen dapat melanjutkan akadnya dengan langsung melakukan pembayaran pada pihak kasir.

Namun, jika tidak setuju terhadap barang tersebut, maka jual beli tidak dilaksanakan. Praktik ini menggambarkan transparansi, di mana tidak ada kedustaan antara kedua belah pihak dan dimaknai sebagai sikap "an taradin" yakni saling ridha yang menjadi syarat mutlak keabsahan dari setiap transaksi menurut Islam. Praktik ini sejalan dengan dengan kaidah "al-Ibrah fi al-Uqud li al-Maqashid wa alMa'ani, la li al-Alfadz wa al-Mabani," bahwa yang menjadi referensi atau tujuan dalam akad adalah substansi dan makna, bukan redaksi atau penamaan. Oleh karena itu, jual beli al-muathah di toko Basmalah di Pulau Mandangin adalah sah menurut hukum ekonomi syariah.

\section{Penutup}

Dari beberapa pembahasan yang telah dipaparkan di atas dapat disimpulkan sebagai berikut: Pertama, penerapan akad jual beli di Toko Basmalah Pulau Mandangin, Kabupaten Sampang bahwa jual beli tersebut menggunakan alat elektronik berupa barcode untuk mengetahui spesifikasi barang dan harganya. Kedua, penerapan akad jual beli di Toko Basmalah dalam Pandangan Hukum Ekonomi Syariah adalah sah karena bentuk jual beli tersebut adalah bai' alMuathah, di mana penggunaan barcode ini menjadikan akad (ijab 
qabul) tidak diucapkan karena kedua belah pihak (penjual dan pembeli), sesuai dengan kebiasaan masyarakat setempat, dianggap telah memahami harga barang dan menyetujui untuk melaksanakan jual beli. Hal ini sejalan dengan dengan kaidah "al-Ibrah fi al-Uqud li al-Maqashid wa al-Ma'ani, la li al-Alfadz wa al-Mabani," bahwa yang menjadi referensi atau tujuan dalam akad adalah substansi dan makna, bukan redaksi atau penamaan.

\section{Daftar Pustaka}

An-Nabhani,Taqyuddin. Membangun Sistem Ekonomi Alternatif Perspektif Islam.Surabaya: Risalah Gusti, 2009.

Arikunto,Suharsimi. Prosedur Penelitian Suatu Pendekatan Praktik. Jakarta: Rineka Cipta,2013.

Aziz Muhammad Azam, Abdul. Fiqih Muamalat Sistem Transaksi Dalam Islam.Jakarta: Amzah, 2010.

Basrowi dan Suwandi, Memahami Penelitian Kualitatif.Jakarta: Rineka Cipta, 2008.

Hadi, Abd. Dasar-dasar Hukum Ekonomi Islam. Surabaya: PMN \& IAIN Press, 2010.

Hakim, Lukman. Prinsip-prinsip Ekonomi Islam. Surakarta: Erlangga, 2012.

Sholihin, Ahmad Ifham. Buku Pintar Ekonomi Syariah. Jakarta: Gramedia Pustaka Utama,2010.

J. Moleong, Lexy. Metodologi Penelitian Kulitatif. Bandung: Remaja Rosda Karya, 2005.

-------Metodologi Peneltian Kualitatif Edisi Revisi.Bandung: Remaja Rosda Karya, 2014.

Nuraisyah, Sovi. Analisis Mekanisme Penetapan Harga Jual Dalam Perspektif Prinsip-Prinsip Ekonomi Syariah Studi Kasus Di Toko Arafah Jl.Perjuangan Cirebon. Skripsi, IAIN Syekh Nurjati Cirebon, 2015.

M. Aslianur, "Pemahaman dan Penerapan Akad dalam Transaksi Jual Beli di Pasar Tradisional Studi Terhadap Pedagang Pakaian di Pusat Perbelanjaan Mentaya Kota Sampit”. Skripsi, IAIN Palangka Raya, 2016.

Rusdiyah, dkk. "Shigat Ijab Kabul Transaksi Jual Beli: Perspektif Ulama Kalimantan Selatan.” Al-Banjari. no.2, vol. 14Banjarmasin: JuliDesember: Pascasarjana IAIN Antasari Banjarmasin, 2015.

Sakinah. Fiqih Mu'amalah. Pamekasan: STAIN Pamekasan Press, 2006.

Sugiyono. Metode penelitian Kuantitatif Kualitatif dan R\&D. Bandung: Alfabeta, 2011. 
Penerapan Akad Jual Beli di Toko Modern dalam Pandangan Hukum Ekonomi Syariah (Studi Kasus di Toko Basmalah Pulau Mandangin Kabupaten Sampang)

Al-Fifi, Syaikh Sulaiman Ahmad Yahya. Ringkasan Fiqih Sunnah Sayyid Sabiq. Jakarta: Pustaka Al-Kautsar, 2009,

Tim Penyusun.Pedoman Karya Ilmiah. Pamekasan: Sekolah Tinggi Agama Islam Negeri Pamekasan, 2015.

Fauzia, Ika Yunia, dkk. Dasar Ekonomi Islam Perspektif Maqasid alSyari'ah. Jakarta: Prenada Madia Group, 2014.

http://bmtugtsidogiri.co.id/berita-220.html. diakses tanggal 12 Maret 2018.

http://www.maqonsae.Com/2017/12/pengalaman-belanja-ditokobasmalah.html?m=1. diakses tanggal 12 Maret 2018. 